\title{
Studi Fenomenologis Tentang Implementasi Tata Kelola Perguruan Tinggi Badan Hukum di Indonesia
}

\author{
Yusar Sagara ${ }^{1 *}$, Santi Yustini ${ }^{2}$ \\ 1,2 Universitas Islam Negeri (UIN) Syarif Hidayatullah Jakarta \\ 1yusar.sagara@uinjkt.ac.id, ${ }^{2}$ santi.yustini@uinjkt.ac.id \\ ${ }^{*}$ Penulis Korespondensi
}

\begin{abstract}
This study examines the laws and regulations that form the legal basis of governance of state universities and their implications for academic and non-academic autonomy. The purpose of this study is to find answers to policies and practices of academic and non-academic governance and find alternative support of university management concepts and practices from the study of laws and regulations on higher education and legislation on state finance. Data analysis is using qualitative by studying the ideal concept (according to regulation, observation and documentation). The results of this study conclude that the governance of state universities in the context of academic autonomy is still too dominated by the government. In non-academic autonomy is also not yet fully implemented such as organizational structure, staffing, finance, and international cooperation.
\end{abstract}

Keywords: state university administration, academic Autonomy, non-academic autonomy

\begin{abstract}
Abstrak
Studi ini meneliti hukum dan peraturan yang membentuk dasar hukum tata kelola universitas negeri dan implikasinya bagi otonomi akademik dan non-akademik. Tujuan dari penelitian ini adalah untuk menemukan jawaban terhadap kebijakan dan praktik tata kelola akademik dan non-akademik dan menemukan dukungan alternatif dari konsep dan praktik manajemen universitas dari studi hukum dan peraturan tentang pendidikan tinggi dan undang-undang tentang keuangan negara. Analisis data menggunakan kualitatif dengan mempelajari konsep ideal (sesuai dengan regulasi, observasi dan dokumentasi). Hasil penelitian ini menyimpulkan bahwa tata kelola perguruan tinggi negeri dalam konteks otonomi akademik, masih terlalu didominasi oleh pemerintah. Dalam otonomi nonakademik juga belum sepenuhnya dilaksanakan seperti struktur organisasi, kepegawaian, keuangan, dan kerjasama internasional.
\end{abstract}

Kata Kunci: administrasi universitas negeri, otonomi akademik, otonomi non-akademik 


\section{PENDAHULUAN}

Tata kelola pendidikan di Indonesia khususnya perguruan tinggi negeri selanjutnya disebut PTN semakin mendapat tantangan dalam menyikapi persaingan global di tingkat perdagangan dunia. Perguruan tinggi menghadapi permasalahan yang semakin kompleks dalam memasuki era globalisasi. Permasalahan yang dihadapi oleh perguruan tinggi semakin dinamis mulai dari model dan proses penerimaan mahasiswa baru, kecukupan sarana dan prasarana perkuliahan dan laboratorium, rasio dosen dan mahasiswa, kurikulum program studi, pembukaan program studi baru yang sesuai dengan tuntutan dunia kerja dan industri, hasil-hasil penelitian yang belum diaplikasikan, kurang adanya kesinambungan hasil-hasil penelitian yang ditindaklanjuti melalui pengabdian kepada masyarakat, penulisan dan penerbitan karya ilmiah yang masih terbatas. Hal ini dibuktikan dengan data peringkat pendidikan dunia atau World Education Ranking yang diterbitkan pada tahun 2016 oleh (OECD) menentukan, di posisi mana suatu negara maju dalam segi pendidikan. Indonesia menempati urutan ke 57 dari total 65 negara.

Hal senada diperkuat oleh data yang dilansir oleh kemenristekdikti pada tahun 2015 yang menunjukan mutu pendidikan tinggi di Indonesia masih rendah. Dilihat dari rendahnya jumlah pendidikan tinggi di Indonesia yang terakreditasi "A". Dari total 18.264 pendidikan tinggi yang ada di Indonesia hanya 1.845 yang terakreditasi A, 7.480 terakreditasi B, 8.682 terakreditasi $\mathrm{C}$ dan masih terdapat 257 yang belum terakreditasi. Tabel 1 menunjukkan data per 31 Desember 2015.

Tabel 1. Akreditasi Pendidikan Tinggi di Indonesia

\begin{tabular}{|c|c|c|c|c|c|}
\hline \multirow{2}{*}{ Jenjang } & \multicolumn{4}{|c|}{ Akreditasi } & \multirow{2}{*}{$\begin{array}{c}\text { Total } \\
\text { Terakreditasi }\end{array}$} \\
\hline & A & B & C & D (TT)* & \\
\hline Vokasi & 166 & 1.382 & 2.183 & 75 & 3.806 \\
\hline S1 & 1.106 & 4.748 & 5.898 & 175 & 11.927 \\
\hline S2 & 394 & 1.060 & 493 & 5 & 1.952 \\
\hline S3 & 140 & 213 & 69 & 2 & 424 \\
\hline Profesi & 39 & 77 & 39 & 0 & 155 \\
\hline Spesialis & 0 & 0 & 0 & 0 & 0 \\
\hline Total & 1.845 & 7.480 & 8.682 & 257 & 18.264 \\
\hline
\end{tabular}

Sumber: Lakip Kemenristekdikti, tahun 2015

Selanjutnya presentase pendidikan tinggi yang terakreditasi A, B, C dan D (tidak terakreditasi) disajikan dalam bentuk prosentase. Gambar 1 menunjukkan bahwa perguruan tinggi yang terakreditasi $\mathrm{C}$ masih sangat tinggi yaitu 48\% dibandingkan perguruan tinggi terakreditasi B sebesar 41\% dan terakreditasi A sebesar 10\% serta masih terdapat perguruan tinggi yang belum terakreditasi yaitu sebesar $10 \%$ dari total perguruan tinggi yang ada di Indonesia baik negeri maupun swasta serta jenjang vokasi, strata satu (S-1), strata dua (S-2), strata tiga (S-3), profesi dan spesialis. 


\section{Gambar 1. Prosentase Akreditasi Perguruan Tinggi Di Indonesia}

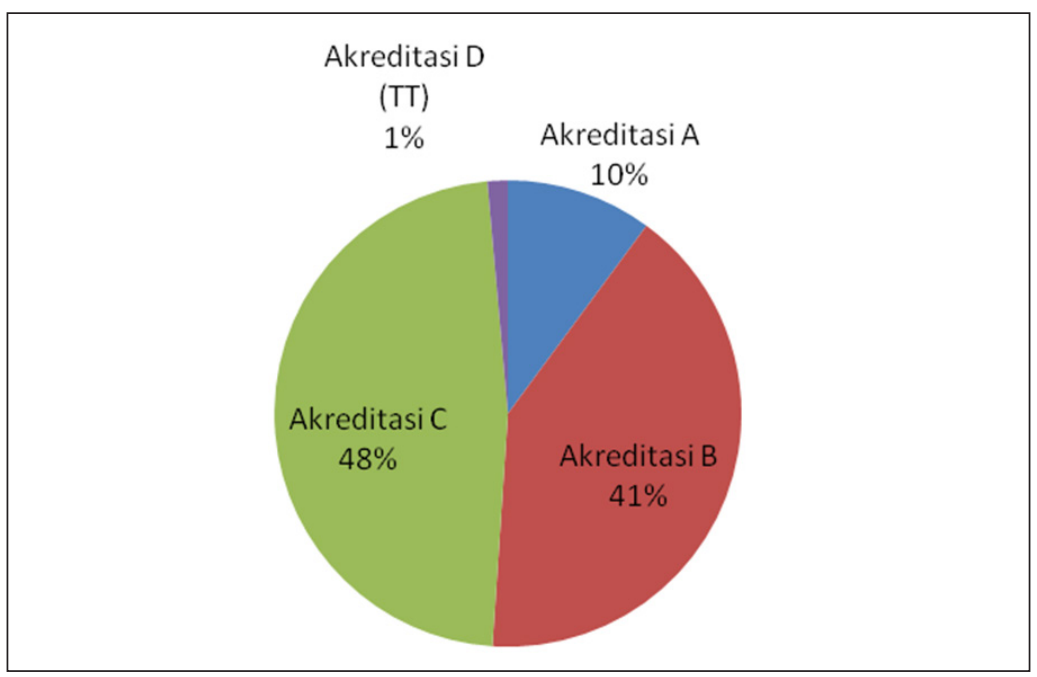

Sumber : Lakip Kemenristekdikti, tahun 2015

The United Nations Development Programme (UNDP) pada tahun 2013, juga melaporkan Indeks Pembangunan Manusia (IPM) atau Human Development Index (HDI) Indonesia masih berada di urutan ke-121 dari 185 negara yang meliputi aspek tenaga kerja, kesehatan, dan pendidikan. Rendahnya mutu pendidikan tinggi di Indonesia dapat dibuktikan dengan data dari Badan Pusat Statistik (BPS) 2015, yakni Tingkat Pengangguran Terbuka (TPT) di Indonesia pada Agustus 2015 menapak 7,56 juta orang. Angka ini setara dengan 6,18 persen dari total 122,4 juta orang angkatan kerja. Sumarno (2011) menyatakan bahwa rendahnya mutu pendidikan tinggi di Indonesia disebabkan oleh rendahnya komitmen pemerintah terhadap pendidikan, kepemimpinan, dan belum diimplementasikanya tata kelola yang baik di pendidikan tinggi. Perguruan tinggi yang menerapkan tata kelola yang baik maka peningkatan dan kelangsungan hidupnya akan terjamin. Kualitas lulusan akan terjamin dengan adanya kepastian dapat lulus tepat waktu dan lulusan akan memenuhi standar kompetensi yang dibutuhkan oleh pasar.

Penelitian ini melakukan implementasi tata kelola perguruan tinggi dengan pendekatan fenomenologis. Tujuan yang ingin dicapai oleh penelitian ini ialah menyusun konsep ideal mengenai tata kelola perguruan tinggi yang baik.

\section{METODE}

Metode penelitian menggunakan pendekatan yuridis normatif dengan penekanan pada data sekunder, berupa review perpustakaan yang didukung oleh pandangan dan argumen dari para ahli dengan teknik wawancara langsung dengan Direktorat Pendidikan Tinggi, Sekretaris Dewan Pendidikan Tinggi, Anggota Senat PTBH (ITB, UGM, IPB, UI, UPI, USU, UNAIR, UNPAD, UNDIP, UNHAS, ITS). Analisis data menggunakan kualitatif dengan mempelajari konsep ideal (sesuai dengan regulasi, observasi dan dokumentasi). 


\section{HASIL DAN PEMBAHASAN}

\section{Kajian Filosofi Good University Governance}

Governance dapat didefinisikan sebagai cara atau mekanisme yang diterapkan oleh suatu organisasi untuk mengatur dan mengendalikan organisasi. UNDP (1997) mendefinisikan governance sebagai pelaksanaan kekuasaan/kewenangan di bidang ekonomi, politik dan administratif untuk mengelola berbagai urusan negara pada semua tingkatan. OECD (2004) menyatakan bahwa governance sebagai suatu cara kekuasaan yang dijalankan dan dikendalikan untuk mencapai tujuan dan bagaimana sumber daya yang ada di atur untuk kepentingan pembangunan di bidang sosial dan ekonomi.

Berdasarkan definisi tersebut dapat dipahami bahwa governance mempunyai tiga perspektif yaitu economic governance yang meliputi proses bagaimana sumber daya ekonomi diatur, dikelola dan dialokasikan secara benar, political governance yang berati mengatur segala sesuatu untuk mencapai suatu tujuan dan administratif governance yang berati bagaimana implementasi dari suatu kebijakan bisa berjalan sesuai dengan yang ditentukan. Dengan kata lain institusi dari governance memiliki tiga domain, yaitu state (Negara atau pemerintah), privat sector (sector swasta dan dunia usaha) dan society (masyarakat) yang saling berinterkasi menjalankan fungsinya masing-masing (Sedarmayanti, 2012)

Selanjutnya governance merupakan suatu istilah yang digunakan di sektor privat atau perusahaan dan di sektor publik termasuk di dalamnya pemerintahan. Dalam sektor privat atau perusahaan dikenal dengan istilah corporate governance atau tata kelola perusahaan dan di sektor publik dikenal dengan public governance, termasuk di dalamnya pemerintahan yang dikenal dengan istilah government governance atau tata kelola pemerintahan. Keseluruhanya menunjukan suatu cara atau mekanisme internal yang disepakati bersama yang diterapkan oleh suatu organisasi untuk mengatur, mengelola dan mengendalikan sesuatu pada berbagai tingkatan agar sesuatu tersebut dapat berjalan sesuai dengan yang ditentukan. Tata kelola sektor publik meliputi kebijakan dan prosedur yang digunakan untuk mengarahkan kegiatan organisasi untuk memberikan keyakinan yang memadai bahwa tujuan terpenuhi dan bahwa operasi dilakukan dengan cara yang etis dan bertanggung jawab (IIA, 2012).

IFAC (2001) menyatakan tata kelola di sektor publik berkaitan dengan struktur, proses pengambilan keputusan, akuntabilitas, kontrol dan perilaku pada organisasi sektor publik. Berdasarkan definisi tersebut dapat disimpulkan bahwa tata kelola (governance) di sertor publik merupakan sistem yang terdiri atas kebijakan dan prosedur yang digunakan sebuah organisasi publik untuk memberikan arah strategis, memastikan tujuan tercapai, mengelola risiko dan menggunakan sumber daya secara bertanggung jawab dengan akuntabilitas. Berdasarkan beberapa definisi yang dikemukan di atas maka yang dimaksud Good University Governance dalam penelitian ini adalah struktur, kebijakan dan prosedur internal universitas yang disepakati bersama oleh internal universitas untuk memberikan arah strategis, memastikan tujuan tercapai, mengelola risiko dan menggunakan sumber daya secara bertanggungjawab dengan akuntabilitas.

Perguruan tinggi adalah bagian sektor publik yang semakin menyadari akan pentingnya konsep governance (Indrajit \& Djokopranoto, 2006). Konsep tata kelola 
universitas diturunkan dari konsep good governance secara umum (Risanty \& Kesuma, 2019). Tata kelola di perguruan tinggi sebagai proses pengambilan keputusan untuk membuat peraturan dan yang mengatur perilaku dan hubungan antara berbagai anggota perguruan tinggi atau komunitas universitas. Dalam tata kelola universitas melibatkan keputusan tentang tujuan dasar atau misi universitas, tentang kebijakan (nilai) yang harus dicapai dengan murni dari misi dasar, tentang program yang akan dilakukan dan tentang sumber daya yang akan diperoleh dan dimanfaatkan. Tata kelola juga melibatkan keputusan tentang tujuan pendaftaran, pengaturan organisasi, standars yang disepakati, persyaratan fasilitas, kebutuhan informasi, alokasi anggaran, dan proses evaluasi. Widjajanti \& Sugiyanto (2015) menjelaskan bahwa tata kelola universitas yang baik akan berdampak pada tingkat kepercayaan stakeholders.

\section{Implementasi Tata Kelola Perguruan Tinggi Badan Hukum}

Konsepsi Pendidikan Tinggi di Indonesia berdasarkan Peraturan Pemerintah nomor 4 tahun 2014 tentang Penyelenggaran Pendidikan Tinggi dan Pengelolaan Perguruan Tinggi, memberikan otonomi kepada perguruan tinggi untuk mengelola sendiri lembaganya. Otonomi dimaksud: 1) Otonomi di bidang akademik; dan 2) Otonomi di bidang non akademik, yang salah satunya meliputi penetapan norma dan kebijakan operasional serta pelaksanaan organisasi, salah satunya bidang keuangan. Otonomi non-akademik (pengelolaan) untuk meningkatkan mutu pendidikan dilaksanakan melalui prinsip GUG. kebebasan yang bertanggungjawab dapat diwujudkan dengan memberikan kewenangan (delegation of autority) melalui otonomi dalam pengertian keseluruhan kemampuan institusi untuk mencapai misinya berdasarkan pilihanya sendiri.

Perguruan tinggi yang otonom, dipersyaratkan memiliki kepastian tentang GUG. Akuntabilitas berupa transparansi check and balance, harus menjadi jiwa dalam tata kelola. Harus dijamin adanya organisasi yang tertib yang mampu memepertanggung jawabkan setiap sen uang di universitas. keuangan yang dapat dipertanggungjawabkan relevansinya dengan kegiatan akademik.

Dengan otonomi ini perguruan tinggi juga dapat menyusun program kerja pendidikan dan pengajaran yang sesuai dengan tuntutan pasar kerja. Selain itu, dapat pula menyusun penelitian yang bermanfaat, pengabdian kepada masyarakat, organisasi yang sesuai, sumber daya manusia yang kompeten, sarana-prasarana yang memadai dan dirumuskan visi, misi, tujuan, sasaran yang dirancang dalam rancangan kerja tahunan, rencana operasionalkan, dan strategi jangja pendek, jangka menengah dan jangka panjang untuk mencapai puncak keuanggulan karya-karya ilmiah yang dihasilkan. Irianto (2012) mengatakan bahwa otonomi perguruan tinggi akan menumbuhkan budaya akademik yang mengajarkan nilai-nilai ilmu pengetahuan, argumentasi dasar ilmiah dalam setiap pengambilan keputusan. budaya akademik yang demikian akan melahirkan hubungan kolegial yang egaliter dan sehat atas dasar saling menghormati dan memberdayakan di antara para ilmuan. Apabila perguruan tinggi dijadikan bagian dari birokrasi pemerintah, akan tumbuh budaya birokrasi yang lamban, tidak efisien dan korup. Perguruan tinggi di indonesia akan semakin tidak mampu 
mengejar perkembangan ilmu dan akan kalah bersaing dengan perguruan tinggi di dunia. Peran negara masih sangat besar dalam pengelolaan perguruan tinggi negeri di Indonesia (Soetjipto dkk, 2014).

PTN di Indonesia dalam perkembanganya mengalami perubahan bentuk dan landasan hukum tata kelolanya. Diawali dengan satker pemerintah, satker pengelolaan keuangan badan layanan umum selanjutnya disebut PTN-BLU, satker perguruan tinggi badan hukum milik negara selanjutnya disebut PTN-BHMN, dan terakhir satker perguruan tinggi badan hukum selanjutnya disebut PTN-BH. Dalam kerangka reformasi keungan negara berdasarkan UU No.17/2003 Tentang Keuangan Negara, UU No.1/2004 Tentang Perbendaharaan Negara dan UU No.15/2004 Tentang Pemeriksaan Pengelolaan dan Tanggungjawab Keuangan Negara.

Sistem keuangan PTN-BH selama ini masih kurang fleksibel dan dikhawatirkan akan menghambat perkembangan yang ada. Seharusnya sistem keuangan PTN-BH bisa secara mandiri dalam bidang akademik maupun non akademik, tetapi pada kenyataannya keuangan pun tidak mandiri karena diatur dengan Kemenkeu. Kemudian dicarikan solusi dengan PP 58/2013 tentang Bentuk dan Mekanisme Pendanaan PTN-BH yang sudah diregulasi, maka diharapkan bisa dilakukan oleh perguruan tinggi tersebut, Selain itu, lanjutnya, perbedaan mendasar antara PTN-BLU dengan PTN-BH terletak pada otonomi akademis yang diberikan, yaitu PTN-BH dapat lebih mandiri dalam membuka dan menutup program studi yang ada di lembaganya, Sedangkan dari aspek keuangan, kewenangan pengelolaan keuangan PTN BLU semuanya swakelola tetapi harus masuk ke APBN dan penentuan honor sangat diatur oleh Kementerian Keuangan.

PTN BLU tidak diperbolehkan mempunyai regulasi sendiri dan rektor juga tidak diberi kewenangan membuat peraturan, sedangkan untuk mengelolaan keuangan PTN-BH bisa lebih fleksibel dengan tetap melaporkannya kepada Kemenristekdikti selaku satker vertikal diatasnya (Laily, 2015). Saat ini penerapan pengelolaan keuangan berbasis kinerja melalui BLU pada PTN masih menimbulkan berbagai permasalahan. Pertama sulitnya PTN untuk beradaptasi dengan sistem pengelolaan keuangan BLU sehingga perbaikan kinerja tidak berjalan baik. Kedua, peraturan yang rumit dan tidak sebanding dengan sumber daya manusia yang kompeten. Hal tersebut menjadi dasar dari adanya keraguan dalam pelaksanaan BLU dimana BLU yang diterapkan pada PTN masih menjumpai berbagai permasalahan sehingga dianggap belum mampu mengembangkan pendidikan dan perekonomian Indonesia. Berdasarkan ulasan tersebut, maka muncul suatu rumusan permasalahan yaitu apakah kekayaan negara dapat dikelola dengan baik oleh PTN sebagai badan layanan umum dalam pengembangan pendidikan dan perekonomian Indonesia.

Data audit BPK laporan hasil pemeriksaan tahun 2015 atas laporan keuangan Kementerian Pendidikan dan Kebudayaan tahun 2014, menunjukkan banyak ketidakteraturan dalam penggunaan anggaran negara di beberapa perguruan tinggi. Tabel 2 menunjukkan beberapa temuan terkait tata kelola di perguruan tinggi negeri. 
Tabel 2. Aspek Ketidakteraturan Penggunaan Anggaran Universitas

\begin{tabular}{cll}
\hline No & \multicolumn{1}{c}{ Perguruan Tinggi } & \multicolumn{1}{c}{ Aspek Ketidakteraturan } \\
\hline 1 & UNAIR, ITSN, UNP, UNANDA, & Terdapat Lebih Bayar Gaji Dan Tunjangan Sebesar Rp1,45 Milyar dan \\
& UPI & Potensi Lebih Bayar Gaji Kepada Pegawai Sebesar Rp365,85 juta
\end{tabular}

Sumber: LHP BPK, tahun 2015

Menurut Irianto (2012) universitas yang baik dipersyaratkan memiliki kepastian tentang governance. Tidak dapat dihindari bahwa universitas merupakan entitas yang utuh dalam tata kelolanya dan tidak terlepas dari aspek keuangan. Universitas harus dikelola secara profesional layaknya mengelola bisnis dalam suatu industri, akan tetapi memegang teguh komitmenya untuk tidak mencari keuntungan yang dibagikan, oleh karenanya keuntungan yang diperoleh harus dapat dimanfaatkan dalam upaya peningkatan dan pengembangan universitas tidak mencari keuntungan yang dibagikan. Penting bagi perguruan tinggi untuk terus meningkatkan tata kelolanya (Abdul, 2016). Perguruan tinggi yang mampu menerapkan tata kelola yang baik akan mampu meningkatkan kinerja manajemen keuangannya (Wahyudin dkk, 2017).

Fenomena belum terimplementasinya prinsip-prinsip university governance di Indonesia dapat dilihat adanya banyak temuan berkaitan dengan pengelolaan keuangan pendidikan. Hasil kajian yang dilakukan oleh Inspektorat VI Inspektorat Jenderal Kementerian Pendidikan dan Keblagu udayaan terhadap 43 universitas dengan jumlah responden 390 unit kerja, terdiri dari 198 fakultas, 15 program pascasarjana, 134 lembaga/UPT, dan 43 pusat/rektorat menunjukan bahwa pengelolaan Penerimaan Negara Bukan Pajak Perguruan Tinggi Negeri (PNBP PTN) pada umumnya belum efektif, hal ini dapat dibuktikan bahwa 90 (23,08\%) responden yang pengelolaan PNBP-nya efektif, 261 (66,92\%) responden kurang efektif dan 39 (10\%) responden tidak efektif.

Belum efektifnya pengelolaan PNBP di Universitas dipengaruhi oleh faktor-faktor kebijakan pimpinan yang tidak tertulis dan tidak tersosialisasi, sumber-sumber penerimaan PNBP, penetapan tarif penerimaan maupun penggunaan, pendapatan pengelolaan PNBP, 
serta belum efektifnya penerapan sistem informasi akuntansi. Perlu adanya sebuah sistem yang berfungsi untuk mengawal dan memberi arahan yang konkret untuk setiap kebijakankebijakan pimpinan institusi. Pada akhirnya sistem informasi akuntansi menjadi sangat diperlukan dan diterapkan guna menuju institusi yang sehat dan bersih dalam berbagai bidang di dalamnya.

Berdasarkan Peraturan Menteri Keuangan No: 119/PMK.05/2007 pasal 5, pola tata kelola merupakan peraturan internal universitas yang menetapkan bahwa organisasi dan tata laksana mencakup struktur organisasi, prosedur kerja, pengelompokan fungsi yang logis, ketersediaan danpengembangan sumber daya manusia serta efisiensi biaya. Akuntabilitas mencakup kebijakan mekanisme/prosedur, media pertanggungjawaban, dan periodisasi pertanggungjawaban program,kegiatan dan keuangan dalam rangka mencapai tujuan yang telah ditetapkan, dan transparansi, dengan menerapkan asas keterbukaan yang dibangun atas dasar kemudahan memperoleh informasi bagi yang membutuhkan (Muljo dkk, 2014). Pasal 115 Ayat (1) PP No.60 Tahun 1999 Tentang Pendidikan Tinggi, otonomi dalam bidang keuangan bagi perguruan tinggi yang diselenggarakan pemerintah mencakup kewenangan untuk menerima, menyimpan dan menggunakan dana yang berasal secara langsung dari masyarakat. Ayat (3) PP No.60 Tahun 1999 Tentang Pendidikan Tinggi, pembukuan keuangan perguruan tinggi yang diselenggarakan oleh pemerintah diperiksa oleh aparat pengawasan fungsional pemerintah sesuai dengan ketentuan perundang-undangan yang berlaku.

Pasal 116 Ayat (1) PP No.60 Tahun 1999 Tentang Pendidikan Tinggi, rencana anggaran pendapatan dan belanja perguruan tinggi yang diselnggarakan oleh pemerintah, setelah disetujui oleh senat perguruan tinggi diusulkan oleh rektor/ketua/direktur melalui menteri, menteri lain, atau pimpinan lembaga pemerintah lain kepada Menteri Keuangan untuk disahkan menjadi anggaran pendapatan dan belanja. Selama ini PTN non BHMN harus menyetorkan dulu ke kas negara seluruh dana yang diterima karena penerimaan dana yang bersumber dari masyarakat, yaitu: (a) sumbangan pembinaan pendidikan (SPP); (b) biaya seleksi ujian masuk perguruan tinggi; (c) hasil kontrak kerja sesuai dengan peran dan fungsi perguruan tinggi; (d) hasil penjualan produk yang diperoleh dari penyelenggaraan pendidikan tinggi; (e) sumbangan dan hibah dari perorangan, lembaga pemerintah atau lembaga nonpemerintah; dan (f) penerimaan dari masyarakat lainnya adalah merupakan penerimaan negara bukan pajak (PNBP), yang harus disetor ke Kas Negara secepatnya dan penggunaan dana tersebut dikembalikan ke kampus lewat rektor melalui mekanisme DIPA/RKAKL. Selain memerlukan waktu yang cukup panjang dan birokratis, proses ini tidak efektif dan efisien terutama apabila perguruan tinggi bersangkutan mendapatkan sumbangan atau hibah atas nama pribadi. Tentu kalau harus setor dahulu ke kas negara akan sangat menyulitkan PTN. Apabila menggunakan sistem yang selama ini berlaku, PTN diwajibkan setor dahulu ke Kas Negara. 


\section{SIMPULAN}

Implementasi tata kelola perguruan tinggi badan hukum masih belum sepenuhnya membentuk karakter yang budaya organisasi yang baik dalam hal kepatuhan dan keteraturan dalam rangka pelayanan dan kinerja sebagaimana dicita citakan. Perubahan bentuk hukum dalam landasan operasional keuangan belum sepenuhnya bisa diimplementasikan sebaiknya menimbulkan berbagai permasalahan terkait implementasi anggaran. Penelitian selanjutnya bisa menambah perspektif sehingga lebih baik.

\section{PUSTAKA ACUAN}

Abdul, A. J. (2016). Penguatan Tata Kelola Kelembagaan IAIN Menuju IAIN Ambon Bermutu Melalui Pelaksanaan Good University Governance. Jurnal Fikratuna, 8(2), 22-35.

IIA. (2006). The Role of Auditing in Public Sector Governance. The Institute of Internal Auditors Research Foundation, Maitland avenue Almonte Spring.

IFAC. (2001). Governance in The Public Sector: A Governing Body Perspektive. IFAC Public Sector Commite.

Indrajit, R. E., \& Djokopranoto, R. (2006). Manajemen Perguruan Tinggi Modern. Yogyakarta: Andi Offset.

Irianto, S. (2012). Otonomi Perguruan Tinggi Suatu Keniscayaan. Cet.2. Jakarta: Yayasan Obor Indonesia.

Laily, I. (2015). Menristekdikti: Keuangan PTN-BH kurang fleksibel. Diperoleh dari sumber: http://www.antaranews.com/.

Muljo, H. H., Wicaksono, A., \& Riantono, I. E. (2014). Optimalisasi Penerapan Prinsip Good Governance Bidang Akademik Dalam Upaya Mewujudkan Good University Governance. Binus Business Review, 5(1), 91-100.

OECD. (2004). The OECD Principlew of Corporate Governance. New York: OECD.

Risanty, R., \& Kesuma, S. A. (2019). Good University Governance: Experience from Indonesian University. Jurnal Perspektif Pembiayaan dan Pembangunan Daerah, 6(4), 515-524.

Sedarmayanti. (2003). Good Governance (Kepemerintahan Yang Baik) Dalam Rangka Otonomi Daerah. Bandung: PT. Mandar Maju.

Soetjipto, A., Seda, F. E., Noor, I. R., Wardani, S. B. E., \& Soebagjo, N. (2014). Otonomi dan Tata Kelola Perguruan Tinggi Negeri Studi Kasus di Universitas Indonesia, Universitas Negeri Jakarta, dan Universitas Islam Negeri Syarif Hidayatullah. Jurnal Masyarakat dan Budaya, 16(2), 293-304.

UNDP. (1997). Governance for suistainable Development Policy Document. New York: UNDP.

Wahyudin, A., Nurkhin, A. \& Kiswanto. (2017). Hubungan Good University Governance Terhadap Kinerja Manajemen Keuangan Perguruan Tinggi. Jurnal Keuangan dan Perbankan, 21(1), 60-69. 
Widjajanti, K., \& Sugiyanto, E. K. (2015). Good University Governance untuk Meningkatkan Excellent Service dan Kepercayaan Mahasiswa (Studi Kasus Fakultas Ekonomi Universitas Semarang). Jurnal Dinamika Sosbud, 17(2), 69-81. 